Dept. of Food Hygiene,

Fac. of Vet. Med., Assiut Univ.

\title{
MICROBIOLOGICAL EVALUATION OF SOME INFANTS POWDERED MILK-BASED FOODS
}

(With 7 Tables)

By

\section{AHMED A-H. AHMED; ENAS EL-PRINCE; EMAN KORASHY* and MARWA M.N. AL-GENDI*}

* Assiut Animal Research Institute

(Received at 15/5/2008)

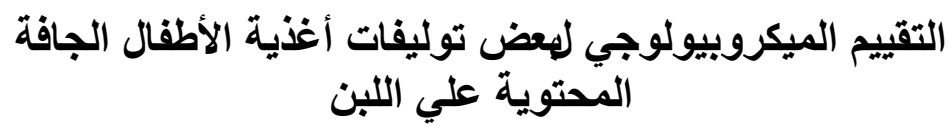

أحمد عبل الحمبل ، إيناس البرنس ، إيبان قرشي ، مروة الجندي

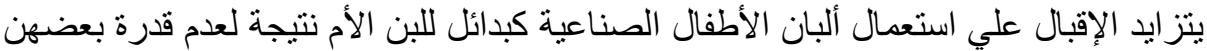

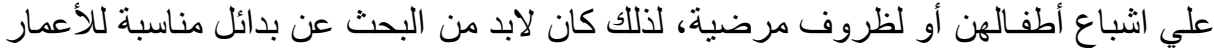

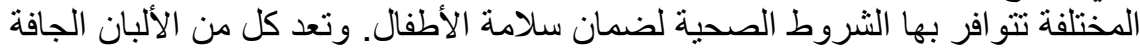

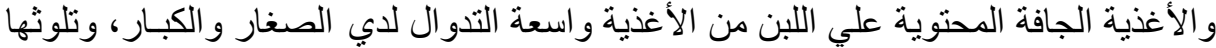

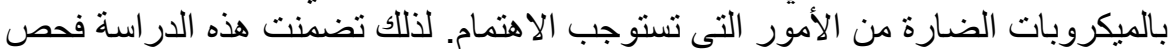

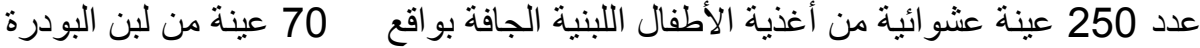

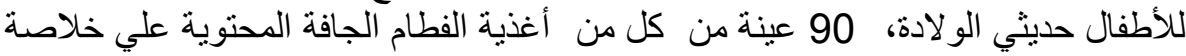

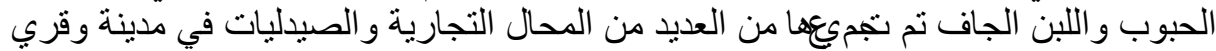

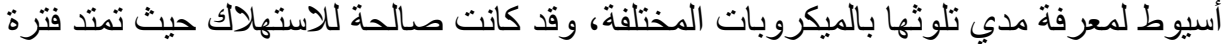

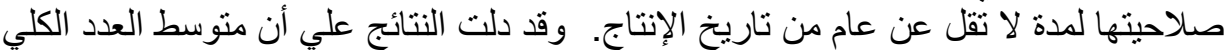

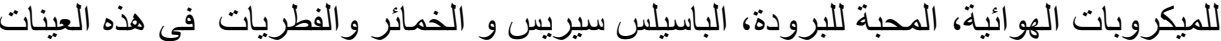

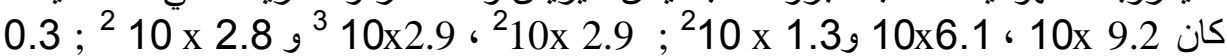

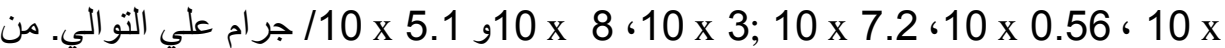

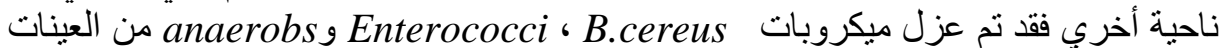

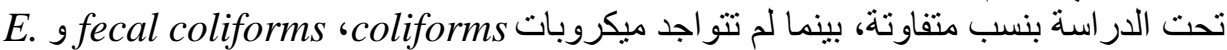
ن coli Enterobacteriaceae

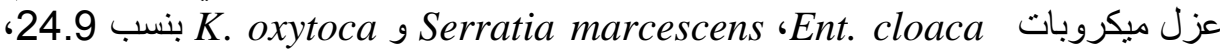

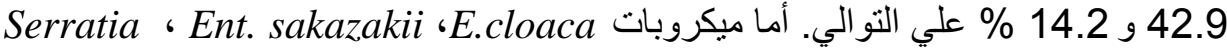

' K. oxytoca ، Ent. aerogenes ‘ Serratia liquefaciens ‘ marcescens 9 Salmonella spp. ، Proteus spp. ، Hafnia alvei 'Citrobacter freundii Chryseomonas luteola 


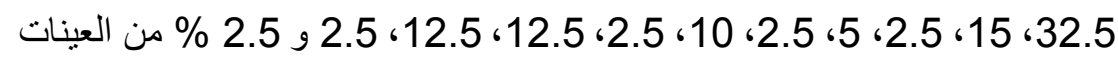

المفحوصة علي الترتيب. من ناحية أخري تبين أس أن

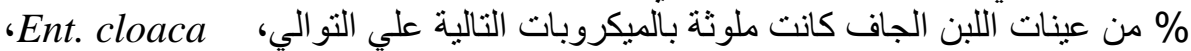
Yersinia pestis 'Hafnia alvei ،Serratia marcescens 'Ent. sakazakii و Yersinia pseudotuberculosis. ومن هذه النتائج أتضح أن أغذية الأطفال المحتوية

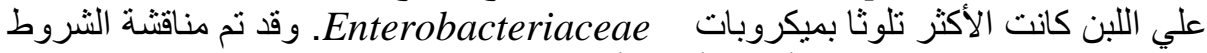
الصحية الواجب اتخاذها لإنتاج ألبان وأغذية أطفال الغات ذات جودة عالية وخالية من الميكروبات

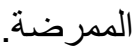

\section{SUMMARY}

A total of two hundred and fifty random samples of infants milk formulae (IMF) for babies after birth (70 samples), milk-based cereal weaning food and dried milk powder (90 samples each) were purchased from different shops and pharmacies in Assiut city and villages around the city. These samples were transferred to the laboratory in their packages to be examined microbiologically to evaluate their quality. The average values of aerobic plate count (APC), psychrotrophic, B. cereus and total yeasts and molds counts were 9.2 $\times 10,6.1 \times 10$ and $1.3 \times 10^{2}$; $2.9 \times 10^{2}, 2.9 \times 10^{3}$ and $2.8 \times 10^{2} ; 0.3 \times 10,0.56 \times 10$ and $7.2 \times 10$ and $3.0 \times 10$, $8.0 \times 10$ and $5.1 \times 10 \mathrm{cfu} / \mathrm{g}$ of examined samples, respectively. Moreover, $B$. cereus, enterococci and anaerobes could be isolated in various percentages from the examined samples. Furthermore, Ent. cloaca, Serratia marcescens and Klebsiella oxytoca were isolated from IMF in percentages of $42.9,42.9$ and $14.2 \%$, respectively. Concerning milkbased cereal baby food, Ent. cloaca, Ent. sakazakii; Serratia marcescens; Serratia liquefaciens; Ent. aerogenes; K. oxytoca; Citrobacter freundii; Hafnia alvei; Proteus spp.; Salmonella spp. and Chryseomonas luteola were found in 13, 6, 1, 2, 1, 4, 1, 5, 5, 1, 1 and 1 of tested samples, respectively. While, Ent. cloaca; Ent. sakazakii; Serratia marcescens; Hafnia alvei; Y. pestis and Y. pseudotuberculosis were existed in dried milk powder samples in incidences of 42.9, 7.1, $7.1,21.4,14.3$ and $7.1 \%$, respectively. Recommendations were suggested to safeguard the existence of such microorganisms in infants' milk food and to avoid their undesirable changes resulted in economic losses as well as public health hazards.

Key words: Microbiological evaluation, Infants milk powder, Milk-based cereal weaning food, Dried milk powder.

\section{INTRODUCTION}


In recent years, there has been a growing use of IMF and baby foods with dairy base as replacers of fresh milk or in addition to it. Milkbased cereal weaning food constitutes a major category, which are fed to babies above 3 months old. Uses of IMF have been decreasing in industrial countries for over forty years as a result of antenatal education, increased understanding of their risks, and social activism. Most major medical and health organizations strongly advocate breastfeeding over their use except in unusual circumstances (WHO, 2001). No other breast milk substitute is as safe as commercial IMF, when produced according to International Standards. Because IMF is not a sterile product, it is an excellent medium to support bacterial growth. Bovine milk is an essential ingredient of IMF and a potential source of bacteria that are pathogenic to humans (Breeuwer et al., 2003). All available data indicate the increased infection risk arising from multiplication of potentially pathogenic bacteria in reconstituted formula kept at room or warmer temperatures for prolonged periods of time (Codex Committee on Food Hygiene, 2004) primarily in hospital neonatal intensive care units (ICU).

Nowadays, the growing use of baby foods has made its microbial quality of primary concern, due to the high susceptibility of children to food-borne diseases. Enterotoxigenic Staph. aureus, Enterococci, Proteus spp. and Clostridial organisms were isolated from baby foods by Becker et al. (1984) and Saudi et al. (1984). Enterobacter spp. were reported as being the fifth and third most common among those recovered from the urinary and respiratory tracts (as nosocomially acquired infections), respectively, of patients in ICU (Jarvis and Martone, 1992 and Borderon et al., 1996). Also, other organisms, as E. coli, Ent. agglomerans, Ent. cloacae, Ent. sakazakii, K. pneumoniae, K. oxytoca, and Citrobacter freundii, were detected in powdered IMF (Iversen et al., 2004). Moreover, dried milk products are known to be frequently contaminated with $B$. cereus, principally with its spores. Viable spores may germinate and the vegetative cells can proliferate and produce toxin; which could potentially even occur at refrigeration temperatures (Becker et al., 1994 and Jaquette and Beuchat, 1998). Furthermore, enterococci existence in samples indicated fecal contamination and unsanitary conditions during handling and production. So, the public health significance can not be denied, specially, when the organisms found in a tremendous number in the product as they have been implicated in several food poisoning outbreaks (ICMSF, 1978). Food-borne diseases also may occur in infants as a result of anaerobes (Bouer-Hertzberger, 1982) or yeasts and 
molds contaminated products which is inactive of unhygienic production.

Enterobacteriaceae are common in food processing environment and their numbers may change as a result of novel contamination, changes in sanitation measures and conditions of growth but they remain prominent and it is hardly possibly to eliminate them (Cox et al., 1988). In heat-processed foods as well as in ready-to-eat foods, the presence of species of this family should have public health significance (Iversen and Forsythe, 2004). Due to the use of baby foods as substitute of/or with mother milk so, the evaluation of their microbial quality is of great concern.

\section{MATERIALS and METHODS}

\section{Collection and preparation of samples:}

A total of two hundred and fifty random samples of IMF (70 samples), milk-based cereal weaning food and dried milk powder (90 samples each) were collected from different shops and pharmacies in Assiut city and villages around the city. These samples were still valid for consumption as their shelf life is at least to be more than one year from production time and were transferred to the laboratory in their packages to be examined microbiologically to evaluate their quality. Cartons and cans of samples were cleaned, thoroughly mixed and aseptically opened. $11 \mathrm{~g}$ of the prepared samples were mixed with $99 \mathrm{ml}$ of sterile $0.1 \%$ peptone water and thoroughly mixed to give a dilution of $1 / 10$ and then ten fold serial dilutions were prepared (A.P.H.A., 1992).

\section{Experimental techniques included:}

1) Aerobic plate count (APC) using Standard plate count agar (A.P.H.A., 1992).

2) Psychrotrophic count using Crystal Violet Tetrazolium agar medium (Gilliland et al., 1976).

3) Enumeration and isolation of B. cereus using Brain-Heart infusion broth and KG agar (Kim and Goepfert, 1971).

4) Total yeasts and molds count using malt extract agar (containing 500 mg each of chlortetracycline and HCL chloramphenicol) (Harrigan and MacCance, 1976).

5) Enterococci count using KF streptococcal agar (Deibel and Hartman, 1982) and isolation using KF broth and KF agar (Morrifon et al., 1997).

6) Detection of anaerobic spore formers: "Stormy fermentation test" (Crückshank et al., 1969). 
7) Total coliforms, fecal coliforms and Escherichia coli count using MPN/ ml (A.O.A.C., 1975).

8) Isolation and identification of Enterobacteriaceae (FDA, 2002) using violet red bile agar (VRBL). Isolates were identified using biochemical tests including Triple Sugar Iron (TSI), Urease test, Sugar fermentation tests, IMViC tests, catalase test then oxidase test.

\section{RESULTS}

The obtained results were recorded in Tables 1- 7.

Table 1: Statistical analytical results of aerobic plate count in the examined samples of powdered milk-based foods.

* Colonies could not be detected on the plates.

\begin{tabular}{|c|c|c|c|c|c|c|}
\hline \multirow{2}{*}{ Type of samples } & \multirow{2}{*}{$\begin{array}{c}\text { No. of } \\
\text { examined } \\
\text { samples }\end{array}$} & No. & $\%$ & Min. & Max. & Average \\
\cline { 3 - 7 } & 70 & 46 & $65.7 \%$ & $*<10$ & $1.5 \times 10^{3}$ & $9.2 \times 10$ \\
\hline Infant milk formulae & 90 & 53 & $58.9 \%$ & $*<10$ & $1.1 \times 10^{3}$ & $6.1 \times 10$ \\
\hline $\begin{array}{c}\text { Milk-based cereal } \\
\text { weaning food }\end{array}$ & 90 & 87 & $96.7 \%$ & $*<10$ & $2.0 \times 10^{3}$ & $1.3 \times 10^{2}$ \\
\hline Dried milk powder & & & & &
\end{tabular}

Table 2: Statistical analytical results of psychrotrophic count in the examined samples of powdered milk-based foods.

* Colonies could not be detected on the plates.

\begin{tabular}{|c|c|c|c|c|c|c|}
\hline \multirow{2}{*}{ Type of samples } & \multirow{2}{*}{$\begin{array}{c}\text { No. of } \\
\text { examined } \\
\text { samples }\end{array}$} & No. & $\%$ & Min. & Max. & Average \\
\cline { 5 - 8 } & 70 & 15 & $21.4 \%$ & $*<100$ & $1.2 \times 10^{4}$ & $2.9 \times 10^{2}$ \\
\hline Infant milk formulae & 90 & 17 & $18.9 \%$ & $*<100$ & $7.8 \times 10^{3}$ & $2.9 \times 10^{3}$ \\
\hline $\begin{array}{c}\text { Milk-based cereal } \\
\text { weaning food }\end{array}$ & 90 & 13 & $14.5 \%$ & $*<100$ & $1.0 \times 10^{4}$ & $2.8 \times 10^{2}$ \\
\hline Dried milk powder & & & & & &
\end{tabular}


Table 3: Statistical analytical results of Bacillus cereus count in the examined samples of powdered milk-based foods.

\begin{tabular}{|c|c|c|c|c|c|c|}
\hline \multirow{2}{*}{ Type of samples } & \multirow{2}{*}{$\begin{array}{c}\text { No. of } \\
\text { examined } \\
\text { samples }\end{array}$} & \multicolumn{2}{|c|}{ Positive samples } & \multicolumn{3}{c|}{ Count / } \\
\cline { 3 - 7 } & & No. & $\%$ & Min. & Max. & Average \\
\hline Infant milk formulae & 70 & 32 & $54.3 \%$ & $*<100$ & $2.0 \times 10^{2}$ & $0.3 \times 10$ \\
\hline $\begin{array}{c}\text { Milk-based cereal } \\
\text { weaning food }\end{array}$ & 90 & 17 & $18.9 \%$ & $*<100$ & $2.0 \times 10^{2}$ & $0.56 \times 10$ \\
\hline Dried milk powder & 90 & 35 & $38.9 \%$ & $*<100$ & $1.8 \times 10^{3}$ & $7.2 \times 10$ \\
\hline
\end{tabular}

* Colonies could not be detected on the plates.

Table 4: Statistical analytical results of total yeasts and molds count in the examined samples of powdered milk-based foods.

\begin{tabular}{|c|c|c|c|c|c|c|}
\hline \multirow{2}{*}{ Type of samples } & \multirow{2}{*}{$\begin{array}{c}\text { No. of } \\
\text { examined } \\
\text { samples }\end{array}$} & \multicolumn{2}{|c|}{$\begin{array}{c}\text { Positive } \\
\text { samples }\end{array}$} & \multicolumn{4}{|c|}{ Count / g } \\
\cline { 3 - 8 } & No. & $\%$ & Min. & Max. & Average \\
\hline Infant milk formulae & 70 & 54 & $77.1 \%$ & $*<10$ & $1.7 \times 10^{2}$ & $3.0 \times 10$ \\
\hline $\begin{array}{c}\text { Milk-based cereal } \\
\text { weaning food }\end{array}$ & 90 & 54 & $60.0 \%$ & $*<10$ & $1.5 \times 10^{3}$ & $8.0 \times 10$ \\
\hline Dried milk powder & 90 & 75 & $83.3 \%$ & $*<10$ & $1.0 \times 10^{3}$ & $5.1 \times 10$ \\
\hline
\end{tabular}

* Colonies could not be detected on the plates.

Table 5: Incidence of different microorganisms in the examined samples of powdered milk-based foods.

\begin{tabular}{|c|c|c|c|c|c|c|c|}
\hline \multirow{2}{*}{ Type of samples } & \multirow{2}{*}{$\begin{array}{c}\text { No. of } \\
\text { examined } \\
\text { samples }\end{array}$} & \multicolumn{2}{|c|}{ B. cereus } & \multicolumn{2}{|c|}{ Enterococci* } & \multicolumn{2}{c|}{ anaerobes } \\
\cline { 4 - 9 } & No.* & $\%$ & No.* & $\%$ & No.* & $\%$ \\
\hline Infant milk formulae & 70 & 32 & $54.3 \%$ & 14 & $20.0 \%$ & 31 & $44.3 \%$ \\
\hline $\begin{array}{c}\text { Milk-based cereal } \\
\text { weaning food }\end{array}$ & 90 & 17 & $18.9 \%$ & 1 & $1.1 \%$ & 49 & $54.4 \%$ \\
\hline Dried milk powder & 90 & 35 & $38.9 \%$ & 12 & $13.3 \%$ & 35 & $38.9 \%$ \\
\hline
\end{tabular}

No. ${ }^{*}$ Number of positive samples

* Colonies could not be detected on the plates, but could be isolated $(<100 / \mathrm{g})$ 
Table 6: Incidence of Enterobacteriaceae in the examined samples of powdered milk-based foods.

\begin{tabular}{|c|c|c|c|}
\hline \multirow{2}{*}{ Type of samples } & \multirow{2}{*}{$\begin{array}{c}\text { No. of } \\
\text { examined } \\
\text { samples }\end{array}$} & \multicolumn{2}{|c|}{$\begin{array}{c}\text { Positive } \\
\text { samples }\end{array}$} \\
\cline { 3 - 4 } & No. & $\%$ \\
\hline Infant milk formulae & 70 & 7 & $10.0 \%$ \\
\hline Milk-based cereal weaning food & 90 & 40 & $44.4 \%$ \\
\hline Dried milk powder & 90 & 14 & $15.6 \%$ \\
\hline
\end{tabular}

Table 7: Frequency distribution of Enterobacteriaceae isolates recovered from positive samples of powdered milk-based foods

\begin{tabular}{|c|c|c|c|c|c|c|}
\hline \multirow[t]{2}{*}{ Enterobacteriaceae isolates } & \multicolumn{2}{|c|}{$\begin{array}{l}\text { Infant milk } \\
\text { formulae }\end{array}$} & \multicolumn{2}{|c|}{$\begin{array}{l}\text { Milk-based cereal } \\
\text { weaning food }\end{array}$} & \multicolumn{2}{|c|}{ Dried milk powder } \\
\hline & No. $/ 7$ & $\%$ & No. $/ 40$ & $\%$ & No. /14 & $\%$ \\
\hline Chryseomonas luteola & - & - & 1 & $2.5 \%$ & - & - \\
\hline Citrobacter freundii & - & - & 1 & $2.5 \%$ & - & - \\
\hline Enterbacter aerogenes & - & - & 1 & $2.5 \%$ & - & - \\
\hline Enterobacter cloaca & 3 & $42.9 \%$ & 13 & $32.5 \%$ & 6 & $42.9 \%$ \\
\hline Enterobacter sakazakii & - & - & 6 & $15.0 \%$ & 1 & $7.1 \%$ \\
\hline Hafnia alvei & - & - & 5 & $12.5 \%$ & 3 & $21.4 \%$ \\
\hline Klebsiella oxytoca & 1 & $14.2 \%$ & 4 & $10.0 \%$ & - & - \\
\hline Proteus spp. & - & - & 5 & $12.5 \%$ & - & - \\
\hline Salmonella spp. & - & - & 1 & $2.5 \%$ & - & - \\
\hline Serratia liquefaciens & - & - & 2 & $5.0 \%$ & - & - \\
\hline Serratia marcescens & 3 & $42.9 \%$ & 1 & $2.5 \%$ & 1 & $7.1 \%$ \\
\hline Yersinia pestis & - & - & - & - & 2 & $14.3 \%$ \\
\hline Yersinia pseudotuberculosis & - & - & - & - & 1 & $7.1 \%$ \\
\hline Total & 7 & $100 \%$ & 40 & $100 \%$ & 14 & $100 \%$ \\
\hline
\end{tabular}

\section{DISCUSSION}

The results presented in Table 1 pinpoint that the average values of $\mathrm{APC} / \mathrm{g}$ were $9.2 \times 10 ; 6.1 \times 10$ and $1.3 \times 10^{2}$ of examined IMF, milkbased cereal weaning food and dried milk powder samples, respectively. In case of IMF, relatively similar findings were obtained by Jarchovská et al. (1980); Saudi et al. (1984); Bhatt et al. (1992); Al-Ashmawy et al. (1993); El-Shinawy et al. (1995) and El-Prince and Korashy (2003). However, lower count was estimated by Schwab et al. (1982) (52/g), 
while Moustafa et al. (1984) and Sabreen (1986) recorded higher counts. Carneiro et al. (2003) detected unacceptable colony counts for the majority of the IMF samples and the contamination rates were related to inadequate handling. According to the limits proposed by A.P.H.A. (1992), Egyptian Standards (2001) and U. S. Dairy Exports Council (1996-2002) of dried milks that, APC must not exceed $5 \times 10^{4} / \mathrm{g}$, therefore, all of examined samples are considered satisfactory. Moustafa et al. (1984); Sabreen (1986); El-Prince and Korashy (2003) and Sayed (2004) recorded higher counts of APC in milk-based cereal baby foods and according to the standards of ICMSF (1974), it is evident that all examined baby food samples were within the range of accepted quality $\left(5 \times 10^{4}-5 \times 10^{5} \mathrm{APC} / \mathrm{g}\right)$. Higher counts were recorded by El-Prince and Korashy (2003) in milk powder. Many authors recommended the APC as an index of hygienic measures, organoleptic quality, safety and utility of infant foods.

The psychrotrophic count ranged from $<100$ to $1.2 \times 10^{4}$ with an average of $2.9 \times 10^{2} / \mathrm{g}$ of IMF samples which are higher than that showed by El-Prince and Korashy (2003). In case of milk-based cereal weaning food, the counts ranged from $<100$ to $7.8 \times 10^{3}$ with an average count of $2.9 \times 10^{3} \mathrm{cfu} / \mathrm{g}$. Higher count was detected by Sayed (2004) however, psychrotrophs were not demonstrated by El-Prince and Korashy (2003). While, in dried milk powder the count lie in between $<100$ to $1 \times 10^{4}$ and an average of $2.8 \times 10^{2} \mathrm{cfu} / \mathrm{g}$ (El-Prince and Korashy, 2003 detected lower finding) (Table 2). In the absence of psychrotrophs or presence of large thermodurics, certain thermoduric psychrotrophs can grow and induce spoilage of the product (Richter et al., 1992 and Meer et al., 1993).

The average counts of $B$. cereus in the concerning samples were $0.3 \times 10 ; 0.56 \times 10$ and $7.2 \times 10 \mathrm{cfu} / \mathrm{g}$, respectively as shown in Table 3 . Moreover, they could be isolated in incidences of 54.3; 18.9 and $38.9 \%$ from the examined samples, respectively (Table 5). Variant counts and percentages were demonstrated by El-Prince and Korashy (2003). Dried milk products, such as milk powder, milk substitute and IMF, contaminated with $B$. cereus, even at low levels should be considered as potential vehicles for food-borne B. cereus disease. As these products contain an elevated level of carbohydrates (starch, sucrose or lactose) and minerals, they can promote proliferation and enterotoxin production when they are reconstituted and held at ambient temperature for extended periods, potentially even at refrigeration temperature (Jaquette and Beuchat, 1998). 
Regarding total yeasts and molds count (Table 4), the results revealed that $77.1 ; 60$ and $83.3 \%$ of the examined samples were contaminated in average counts of $3.0 \times 10 ; 8.0 \times 10$ and $5.1 \times 10 \mathrm{cfu} / \mathrm{g}$. Nearly similar incidence was obtained by Jesenská and Hardinová (1981). Sabreen (1986); El-Shinawy et al. (1995) and El-Prince and Korashy (2003) recorded higher counts in samples of IMF. It is evident that most of positive samples did not comply with the Egyptian Standards (2001) where yeasts and molds must not exceed $10 / \mathrm{g}$. The obtained finding of milk-based cereal baby food was coincident with that reported by Bhatt et al. (1992) (66.67\%). However, higher incidences were postulated by Moustafa et al. (1984) (93.33\%) and Aboul-Khier et al. (1985) while, lower percentages were detected by El-Prince and Korashy (2003) and Sayed (2004). The percentage of yeasts and molds in milk powder agree to a certain extent with that estimated by Bhatt et al. (1992) and Ismail and Saad (1995). While, higher counts and lower percentages $(60 \%)$ were detected by El-Prince and Korashy (2003). Yeasts and molds may grow over a wide range of temperature and gain entrance to milk powder either from the milk used, air contamination or utensils. So, their presence is indicative of unsatisfactory sanitation during processing and handling of the product. The high level of these microorganisms may be due to post heat treatment contamination.

The incidences of enterococci were 20,1.1 and $13.3 \%$ and their numbers were less than $10^{2} / \mathrm{g}$ (could not be detected on the plates) in all the positive examined samples, respectively (Table 5). However, the prevalence of enterococci in dried milk products has been reported by various investigators as Jarchovská et al. (1980); El-Bassiony and Aboul-Khier (1983); Saudi et al. (1984); Sabreen (1986) and Sayed (2004). The prevalence of enterococci in dairy products has long been considered as a result of unhygienic conditions during their production and processing. However, their presence has often been shown to be unrelated with direct faecal contamination (Franz et al., 1999 and Gelsomino et al., 2001).

About the anaerobes (Table 5), they were detected in a percentage of $44.3 \%$ for IMF (lower incidences were detected by Sabreen, 1986 and El-Prince and Korashy, 2003); 54.4\% for milk-based cereal baby food (Sabreen, 1986; El-Prince and Korashy, 2003 and Sayed 2004 detected higher counts) and $38.9 \%$ for dried milk powder. It is worth to mention that, the probability of food-borne illness may occur to children due to consumption of contaminated products with anaerobes 
which is indicative of careless methods of production (BouerHertzberger, 1982).

In addition, coliforms, fecal coliforms and E. coli failed to be detected. Similar findings were obtained by Jarchovská et al. (1980); ElShinawy et al. (1995) and El-Prince and Korashy (2003), while Sayed (2004) could identify only one contaminated sample (3.3\%) in a level of 7.3 MPN/ g. On the other hand, Schwab et al. (1982); Moustafa et al. (1984); Saudi et al. (1984); Sabreen (1986); Bhatt et al. (1992); AlAshmawy et al. (1993) and Carneiro et al. (2003) detected coliforms in most of tested IMF. Our results were in accordance with A.P.H.A. (1992); Egyptian Standards (2001) and U.S. Dairy Exports Council (1996-2002) that coliforms must be less than 10/g and E. coli was absent. The absence of coliforms with failure to detect fecal coliforms and $E$. coli can be considered as an index of satisfactory sanitation.

Furthermore, Enterobacteriaceae existed in the examined samples at percentages of 10, 44.4 and $15.6 \%$, respectively (Table 6). Ent. cloaca, Serratia marcescens and Klebsiella oxytoca were isolated from IMF in percentages of 42.9, 42.9 and 14.2\%, respectively (Table 7). Higher result was recorded by Saudi et al. (1984) who detected Enterobacteriaceae in 52.5\% of IMF. Carneiro et al. (2003) identified $K$. pneumoniae, Citrobacter freundii, Cedacea davisae, K. planticola and Ent. cloacae. While, Iversen and Forsythe (2004); Estuningsih et al. (2006); Shaker et al. (2007) and Townsend et al. (2007) succeeded to isolate Enterobacteriaceae from IMF. Concerning milk-based cereal baby food, Ent. cloaca, Ent. sakazakii; Serratia marcescens; Serratia liquefaciens; Ent. aerogenes; K. oxytoca; Citrobacter freundii; Hafnia alvei; Proteus spp.; Salmonella spp. and Chryseomonas luteola were found in 13, 6, 1, 2, 1, 4, 1, 5, 5, 1, 1 and 1 of the examined samples, respectively (Table 7). Iversen and Forsythe (2004) and El-Prince et al. (2007) could distinguish 14 and 26 isolates related to family Enterobacteriaceae, respectively; however, higher incidences were obtained by Sabreen (1986). Moreover, Ent. cloaca; Ent.sakazakii; Serratia marcescens; Hafnia alvei; Y. pestis and Y. pseudotuberculosis were demonstrated in dried milk powder samples in incidences of 42.9, 7.1, 7.1, 21.4, 14.3 and 7.1 \%, respectively. Iversen and Forsythe (2004) isolated 36 strains of Enterobacteriaceae from examined 72 samples of milk powder, however, El-Prince et al. (2007) could not isolate any strain of this family.

The above achieved results declared that IMF, milk-based cereal baby food and dried milk powder are liable to contamination by some 
pathogenic microorganisms constitute public health hazard. Therefore, sailing of these products should be controlled with health authorities to eliminate potentially occurring hazards arising from microbial pollution.

\section{REFERENCES}

A.O.A.C. (1975): Association of Official Analytical Chemists. Official Methods of Analysis. 12 $2^{\text {th }}$ Ed., Benjamin Franklin Station, Washington.

A.P.H.A. (1992): Standard Methods for the Examination of Dairy Products. $13^{\text {th }}$ Ed., American Public Health Association.

Aboul-Khier, F.; El-Bassiony, T.A.; Ahmed, A-H.A. and Moustafa, M.K. (1985): Enumeration of molds and yeasts in dried milk and ice cream products. Assiut Vet. Med. J., 14 (28): 70-78.

Al-Ashmawy, A.M; Bahout, A.A. and Mansour, M.A. (1993): Microbiological quality of baby foods. Sympoisum on Food Pollution, pp.: 2-12, Fac. Vet. Med., Zagazig Univ.

Becker, H.; El-Bassiony, T.A. and Terplan, G. (1984): Incidence of B. cereus and other pathogenic microorganisms in infant food. Zbl. Bakt. Hyg., I. Abt. Orig. B., 179: 198-216.

Becker, H.; Schaller, W.; Wiese, W. and Terplan, G. (1994): B. cereus in infant foods and dried milk products. Int. J. Food Microbiol., 23: $1-15$.

Bhatt, S.N.; Shah, A.G. and Rana, V.A. (1992): Microbiological status of infant food. J. Food. Sci. Technol., 29 (2): 103-104.

Borderon, J.C.; Lionnet, C.; Rondeau, C.; Suc, A.L.; Laugier, J. and Gold, F. (1996): Current aspects of the fecal flora of the newborn without antibiotherapy during the first 7 days of life: Enterobacteriaceae, Enterococci and Staphylococci. Pathol. Biol., 44: 416-422.

Bouer-Hertzberger, S.A. (1982): Food transmitted diseases of microbial origin. Ph. D. Thesis. Ter Verkryging Van de Graad Van in de diergeneeskunde aan de Prijksuniversitteitte Utrecht.

Breeuwer, P.; Lardeau, A.; Peterz, M. and Joosten, H.M. (2003): Desiccation and heat tolerance of E. sakazakii. J. Appl. Microbiol., 95: 967-973.

Carneiro, L.A.; Silva, A.P.; Merquior, V.L. and Queiroz, M.L. (2003): Antimicrobial resistance in Gram-negative bacilli isolated from infant formulas. FEMS Microbiol. Lett., 228(2):175-179.

Codex Committee on Food Hygiene (CRD6) (2004): Comments by ESPGHAN Committee on Nutrition. Washington DC, USA. 
Cox, L.J.; Keller, N. and Van Schothorst, M. (1988): The use and misuse of quantitive determinations of Enterobacteriaceae in food microbiology. Appl. Bact. Symp. Suppl., 237S-249S.

Crückshank, R.; Duguid, J.P. and Swain, R.H. (1969): Medical Microbiology $11^{\text {th }}$ Ed. E. S. Livingston Limited Edinburgh, London.

Deibel, R.H. and Hartman, P.A. (1982): The enterococci. In: Compendium of Methods for the Microbiological Examination of Foods. M.L., Speck (ed.), $2^{\text {nd }}$ Ed., American Public Health Association.

Egyptian Standards (2001): Dried milks. Egyptian Organization for Standardization and Quality Control.

El-Bassiony, T.A. and Aboul-Khier, F. (1983): Bacteriological evaluation of dried milk products produced in Sakha Processing Dairy Plant. Assiut Vet. Med. J., 11 (20): 159-163.

El-Prince, Enas and Korashy, Eman (2003): Microbiological quality of dried milk-based infant foods in Assiut city. Assiut Vet. Med. J., 49 (97):190-203.

El-Prince, Enas; Sayed, M. and Abdel-Haleem, Amal, A. (2007): Incidence and public health hazard of E. sakazakii in milk powder and some dried milk-based foods. Assiut Vet. Med. J., 53 (113): 124- 137.

El-Shinawy, Saadia, H.; Abdel-Aziz, Aida, M. and El-Hady, H.A. (1995): Microbiological quality of infant powdered milk. J. Egypt. Vet. Med. Assoc., 55 (1,2): 147-154.

Estuningsih, S.; Kress, C.; Hassan, A.A.; Akineden, O.; Schneider, E. and Usleber, E. (2006): Enterobacteriaceae in dehydrated powdered infant formula manufactured in Indonesia and Malaysia. J. Food Prot., 69 (12):3013-3017.

FDA (Food and Drug Administration), Center for Food Safety and Applied Nutrition (2002): Isolation and enumeration of $E$. sakazakii from dehydrated powdered infant formula. Available at http://www.cfsan.fda.gov/ comm/mmesakaz.html.

Franz, C.M.A.P.; Holzapfel, W.H. and Stiles, M.E. (1999): Enterococci at the crossroads of food safety?. Int. J. Food Microbiol., 47: 124.

Gelsomino, R.; Vancanneyt, M.; Condon, S.; Swings, J. and Cogan, T.M. (2001): Enterococcal diversity in the cheese making environment of an Irish Cheddar-type cheese making factory. Int. J. Food Microbiol., 71: 177-188. 
Gilliland, S.E.; Michener, H.D. and Kraft, A.A. (1976): Psychrotrophic microorganisms. In: Compendium of Methods for the Microbiological Examination of Foods. M.L. Speck (ed.) $2^{\text {nd }}$ Ed., American Public Health Association.

Harrigan, W.F. and MacCance, M.E. (1976): Laboratory Methods in Food and Dairy Microbiology. Acad. Press, London, New York.

ICMSF (International Commission on Microbiological Specifications for Foods) (1974): Microorganisms in foods. Vol. 2, P.: 128. Sampling for microbiological analysis: principles and specific applications. Univ. of Toronto Press, Toronto.

ICMSF (International Committee on Microbiological Specification for Foods) (1978): Microorganisms in food. Their significance and methods of enumeration. $2^{\frac{\text { nd }}{4}}$ Ed., Univ. of Toronto Press, Toronto, Buffalo London.

Ismail, M.A. and Saad, Nagah, M. (1995): Studies on the mycological quality of milk powder. Assiut Vet. Med. J., 32 (64): 173-185.

Iversen, C. and Forsythe, S.J. (2004): Isolation of E. sakazakii and other Enterobacteriaceae from powdered infant formula and related products. Food Microbiol., 21:771-776.

Iversen, C.; Lane, M. and Forsythe, S.J. (2004): The growth profile, thermotolerance and biofilm formation of E. sakazakii grown in infant formula milk. Letters in Appl. Microbiol., 38: 378382.

Jaquette, C.B. and Beuchat, L.R. (1998): Survival and growth of psychrotrophic $B$. cereus in dry and reconstituted infant rice cereal. J. Food Prot., 61: 1629-1635.

Jarchovská, H.; Koudelka, J. and Lukášvá, J. (1980): Microbiological quality of infant foods made from dried milk in Czechoslovakia. Veterinarní Medicína, 25 (11): 691-695. Dairy Sci. Abst. 43, 5418, (1981).

Jarvis, W.R. and Martone, W.J. (1992): Predominant pathogens in hospital infections. J. Antimicrob. Chemother., 29 (Suppl. A): 19-24.

Jesenská, Z. and Hardinová, I. (1981): Molds in foods in Czechoslovakia. Schimmelpilze in Lebensmitteln der Tschechoslowakei. Zeitschrift für Lebensmittel- Untersuchung und-Forschung., 173 (1): 16-20. Dairy Sci. Abst. 44, 347, (1982). 
Kim, H.U. and Goepfert, J.M. (1971): Enumeration and identification of B. cereus in foods. Appl. Microbiol., 22: 581- 587.

Meer, R.R.; Wodburn, M.J. and Bodyfelt, F.W. (1993): Identification and characterization of heat-resistant psychrotrophic bacteria in Oregon Grade A raw milk. Dairy, Food and Environ. San., 13 :631-637.

Morrifon, D.; Woodford, N. and Cookfon, J. (1997): Enterococci as emergent pathogen of humans. J. Appl. Microbiol. Symposium Supplement, 83, 89s- 99s.

Moustafa, M.K.; Ahmed, A-H. A.; El-Bassiony, T.A. and Aboul-Khier, F. (1984): Microbiological quality of infant milk foods. Assiut Vet. Med. J., 12 (24): 163-168.

Richter, R.L.; Ledford, R.A. and Murphy, S.C. (1992): Milk and milk products In: Compendium of Methods for the Microbiological Examination of Foods. C. Vanderzant, and D.F. Splittstoesser, (eds.), $3^{\text {rd }}$ Ed., pp.: 841-843, American Public Health Association, Washington, DC., USA.

Sabreen, M.S. (1986): Microflora in baby foods. M. V. Sc. Thesis, Fac. Vet. Med., Assiut Univ., Egypt.

Saudi, A.M.; El-Essawy, H.A. and Moursy, A.W. (1984): Bacteriological quality of infant milk foods. Assiut Vet. Med. J., 12 (23): 137142.

Sayed, M. (2004): Microbiological quality of baby foods. Assiut Vet. Med. J., 50 (102): 72- 79.

Schwab, A.H.; Swartzentruber, A.; Wentz, B.A. and Read, R.B. Jr. (1982): Microbiological quality of dry-milk mixes and milk substitute infant formulas. Appl. Environ. Microbiol., 43 (2): 389-391.

Shaker, R.; Tareq, O.; Wail, A.; Ziad, J. and Mahmoud, A. (2007): Isolation of E. sakazakii and other Enterobacter spp. from food and food production environments. Food Control, 18 (10): 1241-1245.

Townsend, S.; Caubilla, J.B.; Loc-Carrillo, C. and Forsythe, S. (2007): The presence of endotoxin in powdered infant formula milk and the influence of endotoxin and E. sakazakii on bacterial translocation in the infant rat. Food Microbiol., 24 (1): 67-74.

U. S. Dairy Exports Council (1996-2002): U.S. Standards for milk powders. American Dairy Products Institute, Bulletin \# 916.

WHO (World Health Organization) 2001. Executive Board "Infant and Young Child Nutrition". World Health Organization. 